\title{
わが国における小児心臓移植の展望と移植後管理
}

\begin{tabular}{|l} 
布田 伸一 \\
東京女子医科大学東医療センター心臟血管診療部
\end{tabular}
Key words:

pediatric heart transplantation, indication, post-transplant care, mTOR (mammalian target of rapamycin) inhibitor

\section{Pediatric Heart Transplantation in Japan: Future Prospects and Post-transplant Care}

Shinichi Nunoda

Cardiovascular Division, Tokyo Women's Medical University Medical Center East, Tokyo, Japan

A revised transplant law, which has been valid since July 17, 2010, has provided the same circumstances of organ donation in the United States, that is, organ donation from donors of any age has been valid with the opt-in system. Adult heart transplantation has been performed at the rate of three cases a month since then; however, only one pediatric heart transplant was done from a brain-dead donor less than 15 years old. In order to do more pediatric heart transplants in Japan, pediatric intensive care units in each hospital in Japan should communicate with the three pediatric heart transplant centers in Japan. It is also important that a pediatric ventricular assist devices, such as the ExCor · Pediatric, be approved as soon as possible. For making well-established pediatric heart transplantation in the future, post-transplant care for pediatric heart transplantation must be prepared.

\section{要旨}

2010 年 7 月 17 日の改正臓器移植法施行により, それまで 15 歳未満の臟器提供が禁じられ, 年に 10 例程度し か成人心臓移植が行われなかった状況から，環境は一変し，それまで閉ざされていた国内における幼小児の心臓 移植の道が開かれた。しかしながら，現実では国内における 15 歳未満の臓器提供者からの小児心臓移植例は， 2011 年 12 月時点で, 2011 年 4 月に 10 代後半の小児行われた 1 例のみである。成人心臟移植の方は着実に例数 を積み重ねているのに対し，小児心臓移植数が延びないのはなぜだろうか．本稿では，わが国に㧍ける小児心臓 移植定着に向けての問題点と, 将来の小児心臟移植定着に備えて, 成人とは異なる移植後管理について述べたい.

\section{はじめに}

2010 年 7 月 17 日の改正臓器移植法施行により, そ れまで 15 歳未満の臟器提供が禁じられ，年に 10 例程 度しか成人心臓移植が行われなかった状況から，環境 は一変し，欧米各国と法的には同様な状態になった， つまり，それまで閉ざされていた国内に扔ける幼小児 の心臟移植の道が開かれた。しかしながら，現実では 国内に打ける 15 歳未満の臓器提供者からの小监心臓 移植例は，2011年 12 月時点で，2011 年 4 月に 10 代 後半の小児行われた 1 例のみである. 改正臓器移植法
施行後に成人心臓移植の方は着実に例数を積み重ねて いるのに対し，小児心臓移植数が伸びないのはなぜだ ろうか，疑問点は，今後の改善点に繋がるものと思わ れる。

いずれは軌道に乗るであろう小览心臓移植だが，そ の移植後管理は成人とは異なる部分もある。その準備 は，周到にしておかなければならない．

臓器移植は，ドナーとレシピエントの両者が存在し て初めて成り立つ医療である。本稿では，小児心臓移 植の臟器提供者(ドナー)のために，そして提供された 心臓を受ける重症心不全患者(レシピエント)のため
2012 年 1 月 10 日受付 2012 年 1 月 13 日受理
別刷請求先：干 116-8567 東京都荒川区西尾久 2-1-10

東京女子医科大学東医療センター心臟血管診療部 布田 伸一 
に,わが国における展望と移植後管理について述べた w.

\section{小児心臓移植についてのわが国の現状と問題点}

1. 世界における小児心臟移植レジストリーからみた わが国の展望

わが国の状態を論じる前に，世界の状況を知ってお く必要がある. 国際心・肺移植学会 (ISHLT) から出さ

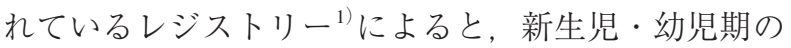
心臟移植は, 成人心臟移植の成績が臨床的に安定して きた 1980 年代後半以降に飛躍的に増加し，1991 年以 降はプラトーに達しており年間 450 例前後が行われて いる. 成人を含めた全心移植件数は過去 10 年間で, 年間 3,600 3,850 件行われており, 統計が開始され た 1982 年から 2009 年の間に 97,911 例の心臓移植の うち 18 歳未満は 9,566 例である。つまり, 全心臓移 植の約 $10 \%$ が小児例ということになる。施行年齢は, 1 歳未満が年間 $100 \sim 150$ 例, $1 \sim 10$ 歳と $11 \sim 17$ 歳 では，それぞれ $150 〜 200$ 例ずつである ${ }^{1)}$ (Fig. 1).

具体的に，日本において小児心臓移植が実際にどれ くらい行われるのかについては, 改正臟器移植法施行 (2010 年 7 月 17 日) から 2011 年 11 月 30 日までの 15 カ月間に計 48 例 (38 例 / 年) のペースで心臓移植が行 われていることから，法律が欧米並みになったわが国 では 38 例の $10 \%$ である 4 例は少なくとも行われてい なければならないことになる。現実的には，この間の 小児心臟移植は 15 歳未満の脳死提供者から 10 代後半 レシピエントに移植された例と 18 歳未満の脳死臓器
提供者からの計 2 例だけであり, 10 歳未満の小児には, いまだ移植されていない現状である。日本小児循環器 学会による 5 年間の全国調査 ${ }^{2}$ では, 15 歳未満の 135 例中 $45 \%$ が心臓移植適応という回答であり, 少なく とも年間 12 例が心臓移植の適応となる。現状は, こ の数字にはまったく届かない，また全国調査 ${ }^{2}$ で適応 と判定された時点での平均年齢は 9.8 歳であったこと より，わが国の小児心臟移植の定着には，どうしても 10 歳以下の重症心不全小児患者がコンスタントに移 植されることが不可欠である。

\section{2. 小児心臓移植適応基準について}

わが国における心臟移植適応基準は, 日本循環器学 会 (日循)心臓移植委員会によって定められており, 改 正臟器移植法施行で小児心臟移植実施が具体化されて きたため, 先天性心疾患例の多い小児例に対しても判 定しやすい形になっている。具体的には, 以前は成人, 小児を問わず， 1 種類の書式であったが，今回新たに 11 歳未満用のものを追加し, 計 2 種類の申請用紙が 用意されている (http://plaza.umin.ac.jp/ hearttp/). ISHLT のレジストリーでも， 1 歳未満の乳児では先天 性心疾患が $58 \%$ ，心筋症が $39 \%$ と先天性心疾患で移 植例が多いことを考えると，先天性心疾患を鑑みた申 請用紙がわが国でも登場したことは以前に比べて申請 しやすい環境となった．ISHLT のレジストリーでは, 1 歳を過ぎると心筋症の適応患者が多くなり, 1 〜 10 歳では心筋症が $54 \%$, 先天性心疾患が $39 \%$ となり, 11 歳以上では心筋症が $62 \%$ となってくる

ここでわが国においては，11歳未満に対する小児

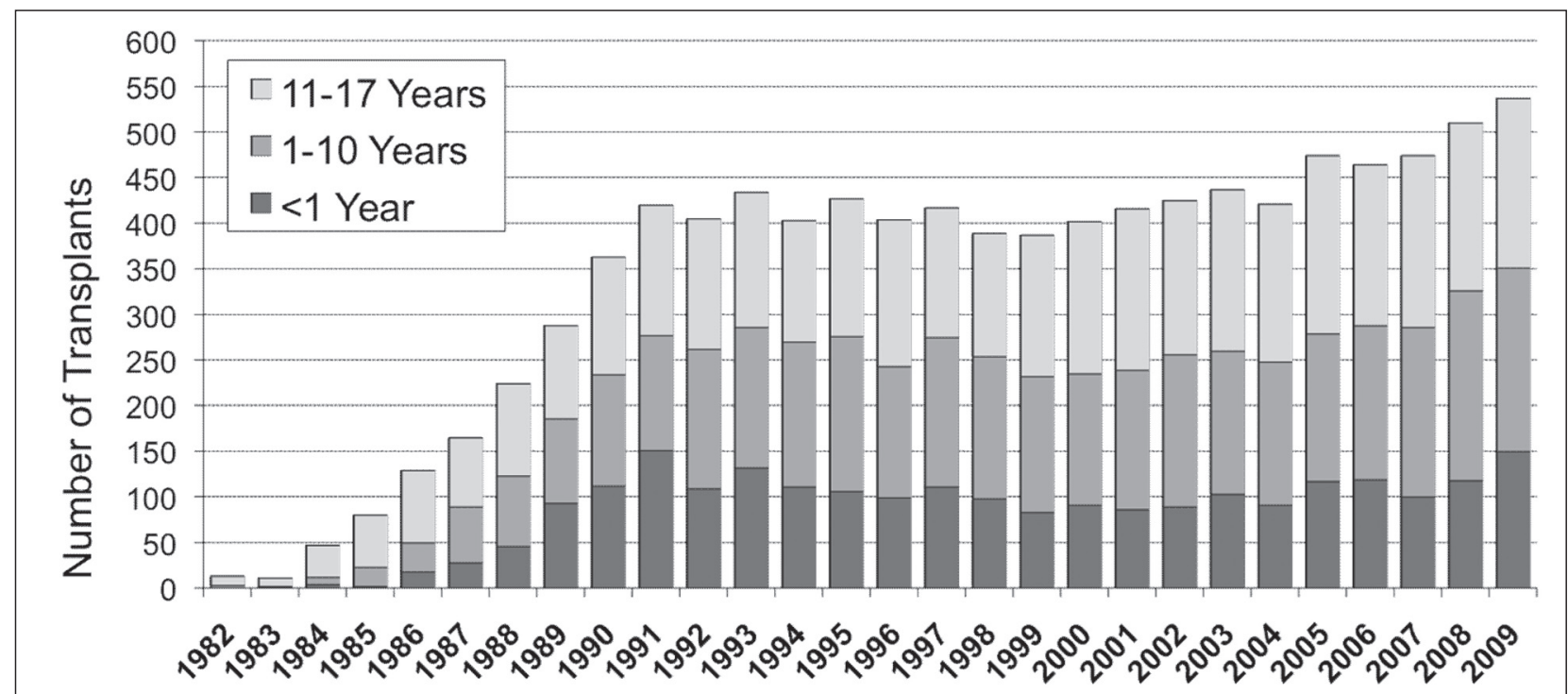

Fig. 1 Age distribution of pediatric heart transplant recipients by year of transplant.

(From reference 1) 
心臓移植施設は, 国立循環器病研究センター病院, 大 阪大学医学部附属病院, 東京大学医学部附属病院の 3 施設において実施することが決められており，成人同 様に, Fig. 2のような手順で申請が進められていく3).

\section{3. 心臓移植待機中の問題について}

日循心臓移植委員会から毎月出されている申請状況 によると, 2011 年 11 月 30 日現在, 15 歳未満で日本 臓器ネットワークに登録中の患者は 23 名であり, 総 数 198 名の $12 \%$ である. 198 名の $2 / 3$ である 124 名が 医学的緊急度の高いStatus 1 であり, 成人や体格的に 問題のない小児では補助人工心臟を装着した状態で待 機している，EVAHEART，Dura Heart等の植込み型補 助人工心臓の場合には, 外来通院しながら待機するこ とも可能となるため, 待機中の QOL は以前に比べる と良好であるが，小さい体格(例えば BSA $1.4 \mathrm{~m}^{2}$ 以下) の小児に対する補助人工心臓は日本には現時点(2011 年 12 月)ではない. 重症心不全が一旦破綻の方向に向 かうと, 二次的な腎機能低下, 肝機能低下が出現し, Status 3 の一旦保留の状態に余儀なくされたり, そう でなくとも重症心不全状態での長期臥床は四肢の筋力 低下を来し, 移植後のリハビリテーションに支障を来 し，強いては移植後に肺炎等の合併症を引き起こす， このように大量カテコラミン投与を必要とする Status 1 の患者には, bridge として補助人工心臟を装着し全 身状態を改善させてから心臓移植をした方が予後は良 好である。

現在, 小児用空気駆動型補助人工心臟 ExCor Pediatric (Berlin Heart GmbH) の治験実施中であり, こ れが使用可能になればECMO (Extra Corporeal Membrane

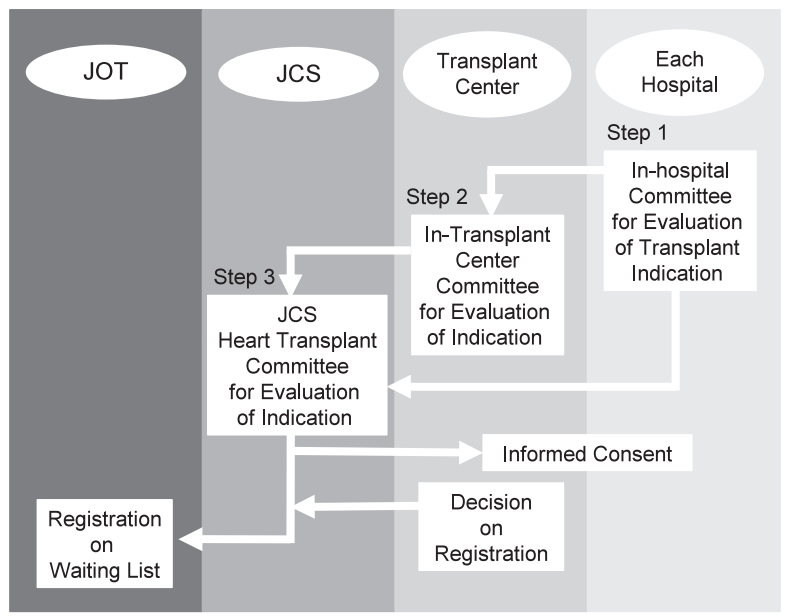

Fig. 2 Process for the evaluation of heart transplant indication and registration on the waiting list in Japan. JOT, Japan organ transplant network; JCS, the Japanese Circulation Society.
Oxygenation)使用が長期化した例，または重症心不全 で血行動態が破綻した例に応用できる，ただし，この ExCor·Pediatric も一般的には $2 \sim 3$ カ月, 長くても 6 力月の使用であり, これも Bridge to Transplantation としての使用であるため, その先の心臟移植，すなわ ちドナーの存在は必須である。

補助人工心臓を装着した患者を管理するためには, 小児集中治療室 (PICU) での管理は余儀なくされるた め, 前述した小児心臟移植実施 3 施設 (国立循環器病 研究センター病院, 大阪大学医学部附属病院, 東京大 学医学部附属病院) の PICU は, 移植待機患者で溢れ てしまうことも予想される. 0 ～1 歳, 1 ～10 歳の心 臓移植対象となるような重症心不全児の多くは全国各 地の小児専門病院に入院しているため, これら小児専 門病院が移植実施施設とより強く連携するシステムが 望まれる.

\section{小児心臟移植管理の重要性}

法的に小児心臓移植実施が可能になったが，前述の 理由により，すぐに待機患者数に見合うドナー確保は 難しい。しかしながら成人心臟移植が始まったときと 同様に，少数の実施例を慎重に管理して良好な成績を 積み上げていくことが，わが国における小览心臓移植 の定着に繋がる。

\section{1. 小児心臟移植に関する危険因子と死因}

小児心臟移植の $1 \sim 5$ 年生存に関わる危険因子とし て, ISHLT のレジストリー ${ }^{1)}$ は, ECMO 使用, 透析使用, 先天性心疾患, 人工呼吸器使用, PRA $\geq 10 \%$, 女児レ シピエント, 等を挙げている.

ここ 10 年間の小児心藏移植の死因としては, 術後 急性期が過ぎた移植後 30 日から 3 年以内では，急性 拒絶反応 $(18.4 \sim 18.7 \%)$ が第一死因で，これは 3 年を 過ぎると減少してくるが，代わりに増えてくるのが，後 述する移植心冠動脈病変 (cardiac allograft vasculopathy: $\mathrm{CAV})$ であり, 5 年以降は第一死因となっている $(\text { Fig. } 3)^{1)}$.

\section{2. 小児心臟移植後管理}

小児の心臓移植後管理は，成人同様に，免疫抑制療 法として, カルシニューリン阻害薬(シクロスポリン かタクロリムス)をべースに, ミコフェノール酸モフェ チル(またはアザチオプリン)とプレドニゾロンを中心 としたステロイドを併用した 3 薬併用療法 (standard triple therapy)で開始され，拒絶反応診断のために心筋 生検と心エコー検査を定期的に行う ${ }^{4)}$.

移植後は，このように免疫抑制薬を絶えず服用しな ければならないため, 免疫抑制薬の副作用も同時にコ 


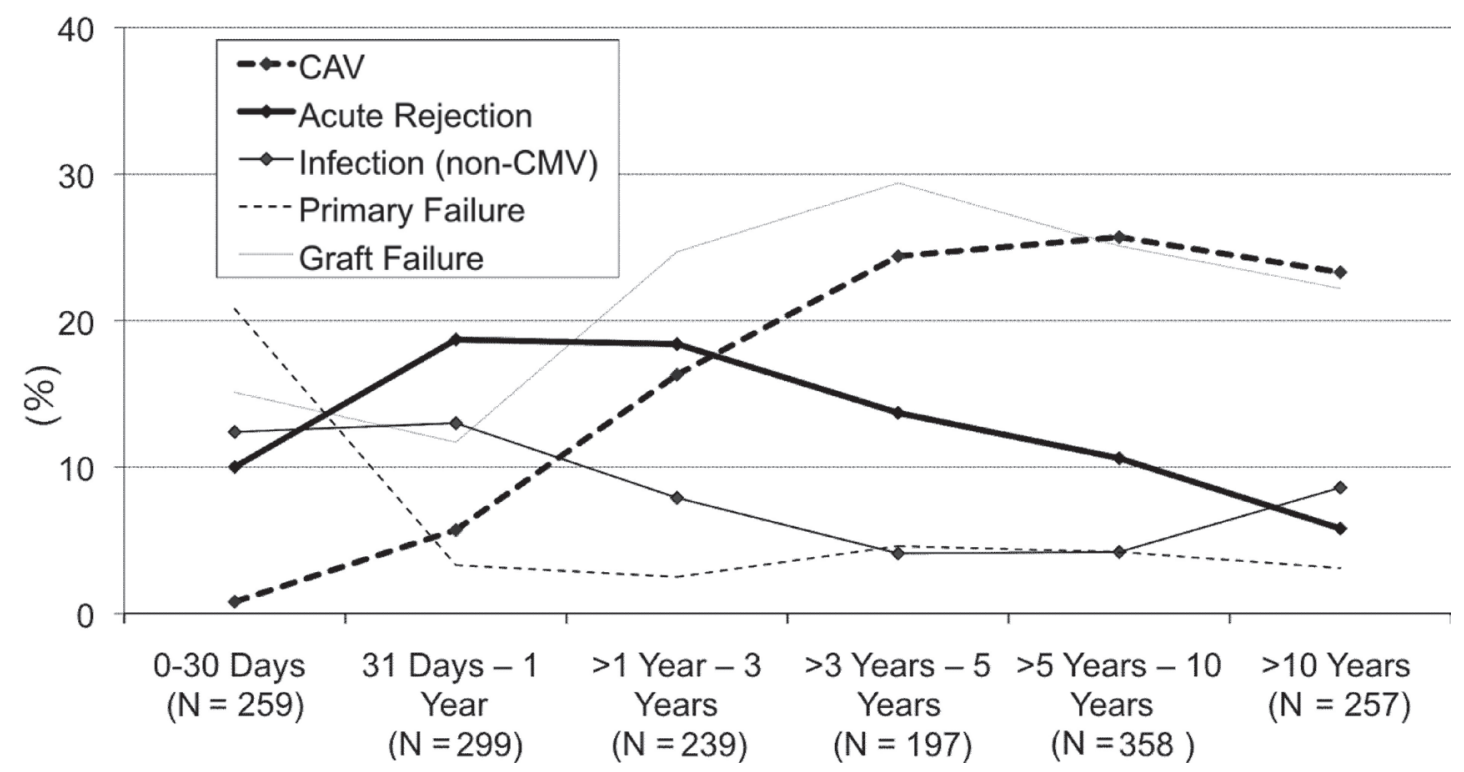

Fig. 3 Relative incidence of leading causes of death from January 1998 through June 2010. CAV, cardiac allograft vasculopathy; CMV, cytomegalovirus.

(From reference 1)

ントロールしていかなければならない，代表的な合併 症には, カルシニューリン阻害薬(シクロスポリンか タクロリムス)による腎機能障害, 高血圧などがあり, 脂質異常症, 歯肉肥厚, 多毛は主にシクロスポリンに, 耐糖能障害は主にタクロリムスで問題となる。 その他, 振戦などの神経障害, 消化性潰瘍, 骨粗鬆症, 膵 - 肝 胆道系疾患なども問題となる。

そして, 小児心臟移植の慢性期の問題としては, CAV と移植後リンパ増殖性疾患 (post-transplant lymphoproliferative disorder：PTLD）を代表とする悪性 腫瘍がある。

\section{(i ) 腎機能障害}

ISHLT レジストリーによると，血清クレアチニン > $2.5 \mathrm{mg} / \mathrm{dl}$ の腎機能障害は, 移植後において直線的に 増加し, 10 年後には $11 \%$ のレシピエントに認められ, その半数に透析療法や腎移植が必要になっている ${ }^{1)}$. したがって移植後も，食事療法に注意しなければなら ない. 自験例の検討 ${ }^{5}$ では, 術後 1 年目から 2 年目の シクロスポリンやタクロリムスが比較的高濃度で推移 している時期はクレアチニンクリアランスの低下を認 めたが，その後はそれら免疫抑制薬の血中濃度が低下 していくにつれて 3 年目, 4 年目は回復する傾向をみ せている。しかしながら，その後移植 7 年目あたりか ら再び低下の方向に転じる症例が散見されるため, 移
植後 4 年目ぐらいまでに，シクロスポリンやタクロリ ムスの血中濃度を十分に低下できるように拒絶反応を 十分にコントロールしておくことが肝心である。移植 後腎機能低下に対する薬物療法としては, レニン・ア ンジオテンシン・アルドステロン阻害薬の投与が第一 選択薬である。

\section{(ii ) 高血圧症}

ISHLT レジストリーによれば，移植後 8 年目までに 約 70\%の小児に高血圧が認められる6 ${ }^{6}$ 。この場合も食 事療法はともかく, レニン・アンジオテンシン・アル ドステロン阻害薬の投与が第一選択薬である.

(iii) 移植心冠動脈病変 (cardiac allograft vasculopathy : CAV)

CAV は，病理学的には,「移植心の心外膜冠動脈か ら心筋内動脈にいたるびまん性で進行性の冠動脈内膜 肥厚」であり，移植心の慢性的虚血を来す。移植心は 除神経心であるため狭心症などの症状を示さず，また 冠動脈の狭窄病変はびまん性のため, 通常の冠動脈造 影では病変をとらえにくく, 冠動脈予備能の低下 ${ }^{7}$, 血管内超音波法 (intravascular ultrasound：IVUS) で肥厚 した血管内膜を観察することで診断される $(\text { Fig. } 4)^{8)}$. このような CAV は小児において移植後 11 年でも $60 \%$ 症例では認められず，成人心移植における出現 
率に比べると有意に低率である ${ }^{1)}$ が，小児のなかでも， 移植時年齢が上がるにつれて CAVの頻度が増してく る。つまり，1歳以下の乳児心臓移植の場合は移植後 8 年経過しても $78 \%$ の例で CAV が認められないのに 対し, 1 〜 10 歳では 75\%の例で， 11 歳以上では 55\% の例で CAV は認められない状況である1).

本病変が出現し進展する原因としては, 免疫学的要 因と非免疫学的要因がある. 免疫学的要因には, 細胞 性および抗体関連 (液性) 急性拒絶反応, サイトメガロ ウイルス感染などが挙げられ，そこには炎症が深く関 与する。つまり，移植後，ドナー心とレシピエントの 血液が最初にコンタクトする場所は冠血管内膜である ことを理解すれば，そこが炎症の起点であることが容 易に理解できる。非免疫学的機序としては, 脳死時 (特 にクモ膜下出血) の大量カテコラミン放出, 移植手術 時のドナー心虚血とその後の再灌流障害, 移植後高血 圧，移植後耐糖能異常，移植後脂質異常症，また高齢 のドナーなどがあり，それらが総合的に本病変を形成 すると考えられている7).

2000 年当初まで移植心冠動脈病変に対しては, そ の発生機序 (免疫学的機序, 非免疫学的機序) から, な
るべく急性拒絶反応を発症させないように管理し，ま た粥状冠動脈硬化症の危険因子である高血圧，脂質異 常症，耐糖能障害等をコントロールし，サイトメガロ ウイルス感染予防を行うことしか術がなかった。つま り危険(促進因子)を出来るだけ軽減するか除去するし か方法がなく，そのためのスタチンや抗血小板薬は現 在も多くの移植施設で使用されている.

経皮的冠動脈インターベンション(percutaneous coronary intervention：PCI）や冠動脈バイパス術 (coronary artery bypass grafting : CABG)の血行再建術 は，びまん性で末梢の冠動脈まで冒される CAVの場 合，標準的治療になっておらず，PCIを施行する場合 には，施行後に生じてくる再狭窄を十分考慮し，後述 する $\mathrm{mTOR}$ (mammalian target of rapamycin) 阻害薬を内 服した状態で，mTOR 阻害薬溶出ステントを使用しな ければならない妾。

この根本的問題を解消すべく，使用できるように なった薬剤が，2007 年の 3 月にわが国でも承認され た mTOR 阻害薬のエベロリムスである.

エベロリムスは，同じ mTOR 阻害薬であるシロリ ムスの誘導体であり，細胞質内の FK506 結合蛋白 12

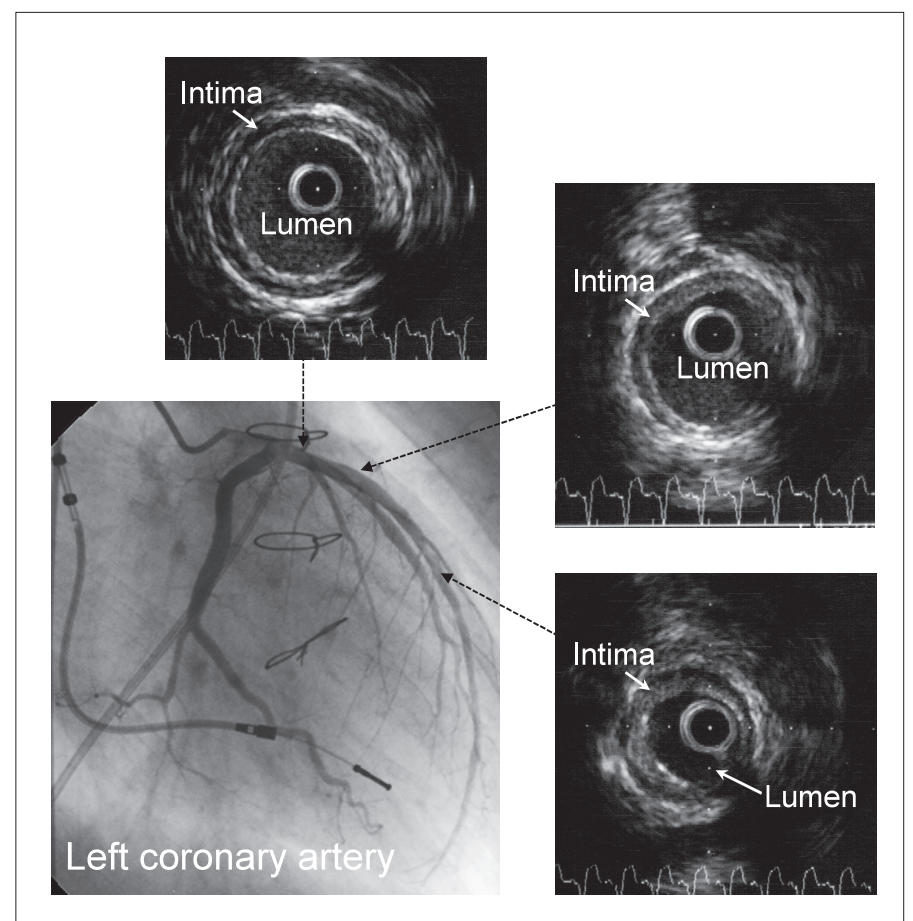

Fig. 4 Visualization of left anterior descending artery by an intravascular ultrasonography in 16-year-old boy. His heart transplantation was done when he was 12 years old, then he received antibodymediated rejection two months post-transplantation and had showed diabetes since five months after the transplantation. Increased intimal thickness was diffusely demonstrated from the proximal to distal portion of his left anterior descending artery. 
（FKBP 12）と複合体を形成し，その複合体が MTORに 結合しキナーゼ活性が抑制されることにより，造血細 胞 ( $\mathrm{T}$ 細胞, $\mathrm{B}$ 細胞), 血管平滑筋細胞, 酵母などで細 胞周期の $\mathrm{G} 1$ 期で停止し $\mathrm{S}$ 期に進まなくさせる。この ような機序から PSI (proliferation signal inhibitor)ともい われている。エベロリムスはシロリムスより半減期が 短く, 副作用も少ないのが特徵であり, エベロリムス を使用した大規模臨床研究では, アザチオプリンに比 して冠動脈内膜肥厚を抑制するばかりでなく，移植後 問題となるサイトメガロウイルス感染症も減らすこと が明らかになった ${ }^{10)}$ 。このエベロリムスは, 小児用量 について記載はないが, 通常, 成人の場合 $1.5 \mathrm{mg}$ を, 1 日 2 回に分けて経口投与し, 患者状態やトラフ濃度 によって適宜増減し，一応 1 日量として $3.0 \mathrm{mg}$ まで 用いる。内服に際しては，食事(特に高脂肪食)が影響 するため，食後または空腹時のいずれかの一定の条件 下で投与することが推奨され, 薬剤相互作用上, 本剂 の吸収と消失は CYP3A4 または P 糖蛋白に影響を及 ぼす薬片に左右される。したがってCYP3A4 を誘導 または阻害する薬剤を併用または中止する場合は，必 ず本剤の血中トラフ濃度 $\left(\mathrm{C}_{0}\right)$ をモニタリングしなけれ ばならないままたCYP3A4で代謝されるカルシニュー リン阻害薬の血中濃度上昇や低下はエベロリムス血中 濃度を増加減少させるため注意が必要である。エベロ リムスの推奨される治療濃度は血中卜ラフ濃度 $\left(\mathrm{C}_{0}\right)$ で $3 \sim 8 \mathrm{ng} / \mathrm{mL}$ とされている ${ }^{11)}$.なお，主な副作用とし ては, 脂質異常症 (特に中性脂肪上昇), 消化器症状, 創傷治癒遅延，細菌感染症，腎機能低下，間質性肺炎， 耐糖の障害などがある，特に男児においては性腺機能 低下を来すことがあり，事前に情報を伝えておく必要 がある。

\section{（iv）悪性腫瘍}

移植後は免疫抑制されるため悪性腫瘍が小児におい ても出現しやすい，その悪性腫瘍のほとんどが小児に おいては PTLDであり, PTLDは成人より小児移植例 で発症が多い ${ }^{12)}$ ．国際心肺移植学会の統計では, 移植 5 年以降の死因の $8.4 \%$ がこのリンパ腫となっている ${ }^{1)}$.

この PTLD はEB ウイルス関連のものが多く, PTLD の治療については, 従来免疫抑制薬の減量や中止, ア シクロビルやガンシクロビルなど抗ウイルス薬の投 与, 多剂併用化学療法が行われてきたが, 最近は抗 $\mathrm{CD} 20$ 抗体の有効性が確立され ${ }^{12,13)}$ ，また前述した mTOR 阻害薬のエベロリムスの効果も報告されている ${ }^{14)}$.

\section{3. 小児心臓移植の生存率と QOL}

ISHLT のレジストリーによると，1歳未満で移植さ れた例の生存曲線は, 移植後早期において他の年齢群 ( $1 \sim 10$ 歳, $11 \sim 17$ 歳) 群に比して死亡率は高いもの の, その後の 20 年間の追跡結果では他の年齢群 $(1$ 〜 10 歳, 11 〜 17 歳)に比して死亡率は低くなっている. 移植後生存率が $50 \%$ を割るのは，1歳未満の乳児は移 植後 18.4 年, $1 \sim 10$ 歳群が 16.4 年, $11 \sim 17$ 歳群が 12.0 年である ${ }^{1)}($ Fig. 5$)$ ．つまり， 0 1 歳児の心藏移 植は術後早期における死亡率は他の年齢群に比して高 いが, 1 〜 年を過ぎて落ち着いてくると，その後は 拒絶反応も生じにくく，生存曲線の右下がり角度は他 の年齢児に比して浅くなり，長期予後は良好である。

前述のように小児心臓移植後には注意しなければな らない点は数多くあるが，それに引き換え移植後の QOL はすこぶる良好である1). ISHLT レジストリーで も移植後 5 年を経過して全介助が必要な児はわずか $1 \%$ である ${ }^{1)}$.

自験例においても，QOL は良好で，移植後の成長 も順調であり，学童児は全例復学している. Fig. 6 に 自験例 (小児)の生存曲線を呈示するが, 26 件と少数 例であるものの, 1 年生存率 $96.2 \%, 5$ 年生存率 $91.3 \%, 10$ 年 $85.3 \%, 20$ 年 $85.3 \%$ と極めて良好な成 績である. 最長で移植後 20 年を経過し, 移植当時, 小学校低学年だった児たちは，成人し，就職してそれ ぞれの道を歩んでいる。一歳で移植した児は，その後 の身体の成長も問題なく, 大学生生活を謳歌している. ドナーの方からの尊い臓器提供により戴いた人生だか らこそ，より光り輝くのかもしれないが，重症心不全 で苦しむ小児たちに明るい未来をもたらすべく，わが 国の小児心臟移植の環境が一日も早く整備されること を願ってやまない.

\section{おわりに}

わが国でようやく法的に小児心臓移植が施行可能に なっても，乳幼児の心臓移植は行われていない，海外 渡航移植も含めて移植後元気になった心臓移植患者の 実態を認識することが，社会的基盤も含めて整備して いく原動力になるように思われる。1997年 10 月施行 の旧臓器移植法の施行後 1 年 4 力月後に長年行われな かった心臓移植が再開されたように，小児心臓移植が 定着するまで，しばらくたゆま努力を続けなければ ならない. 


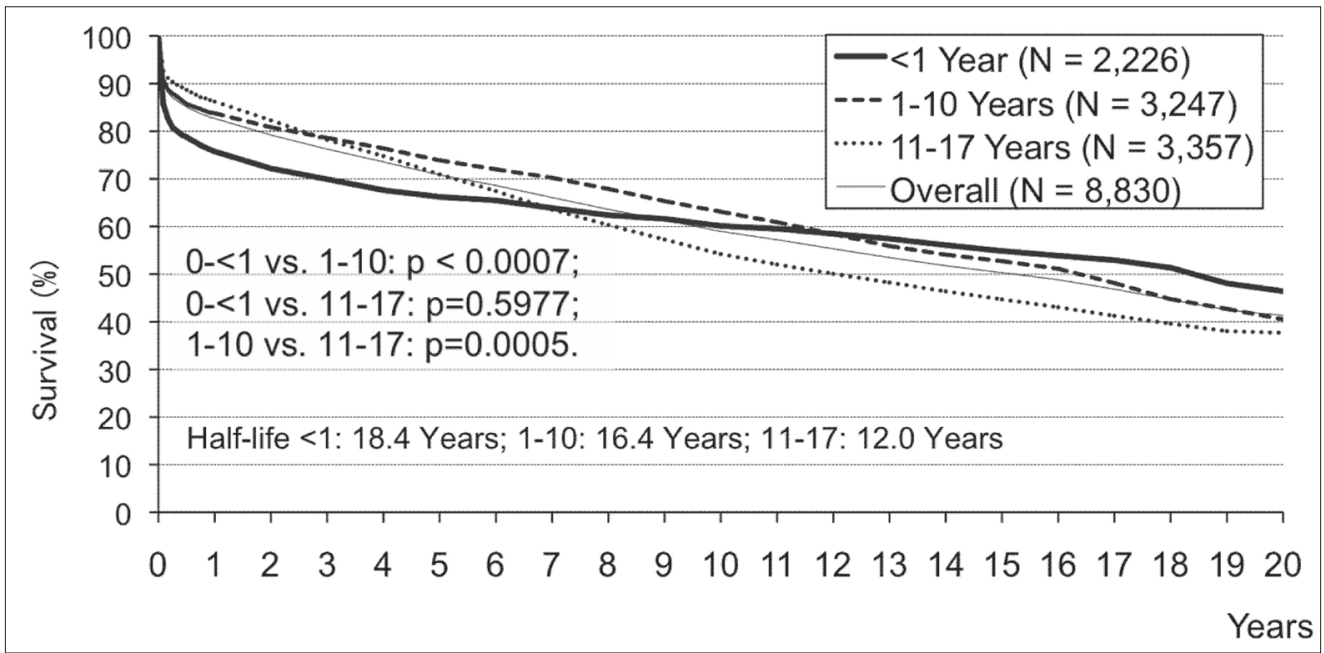

Fig. 5 Kaplan-Meier survival by era for transplants from January 1982 through June 2009.

(From reference 1)

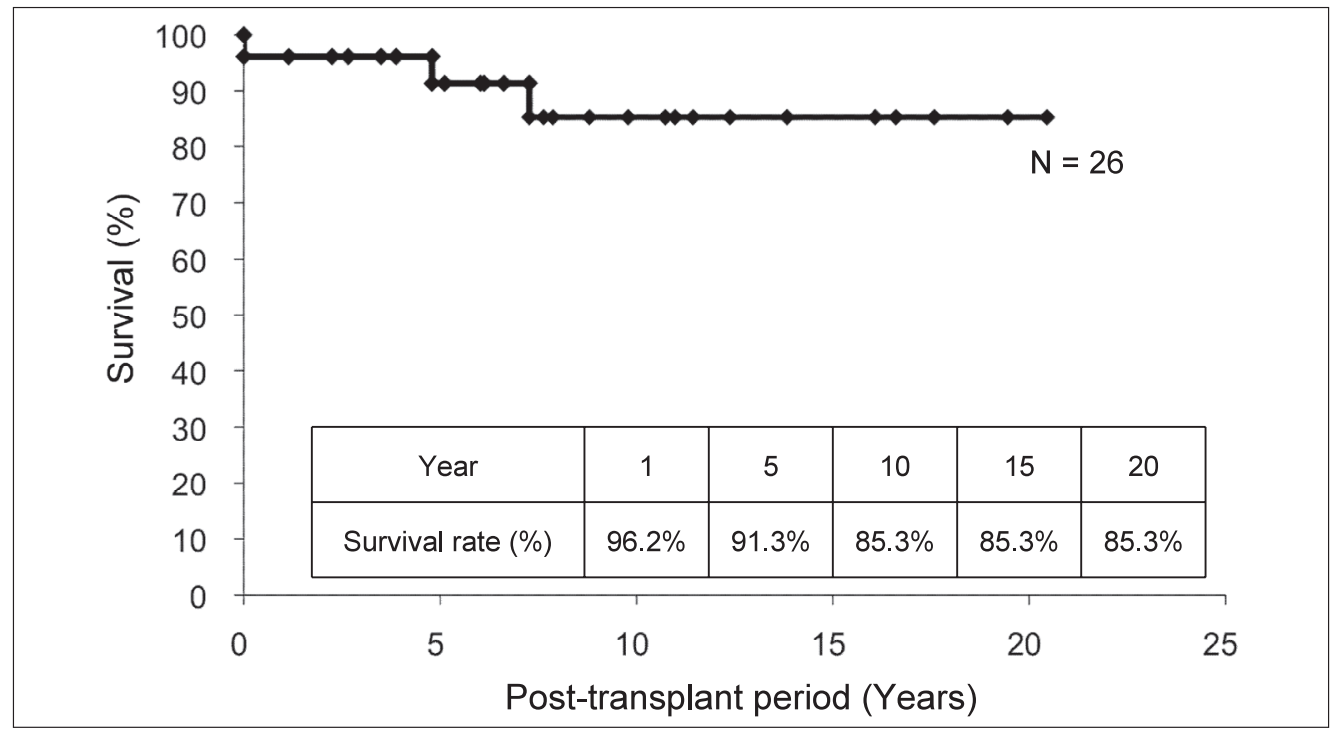

Fig. 6 Kaplan-Meier survival for pediatric transplant patients who have been cared in Tokyo Women's Medical University Medical Center East.

\section{【参考文 献】}

1) Kirk R, Edwards LB, Kucheryavaya AY, et al: The Registry of the International Society for Heart and Lung Transplantation: Registry of the International Society for Heart and Lung Transplantation: Fourteenth Pediatric Heart Transplantation Report-2011. J Heart Lung Transplant 2011; 30: 1071-1132

2) 西川俊郎, 佐治 勉, 井埜利博, ほか: 小児心筋症の全 国調査結果. 日小児循環器会誌 2000; 16: 223-229

3) 西垣和彦: レシピエント登録から移植までの手順: 心藏 移植 (松田暉 監修, 布田伸一, 福嶌教偉 編). 東京, シュ プリンガー・ジャパン株式会社, 2011, pp39

4)布田伸一: 細胞性拒絶反応の診断と治療: 心藏移植 (松
田睴 監修, 布田伸一, 福嶌教偉 編). 東京, シュプリン ガー・ジャパン株式会社, 2011, pp245-250

5)布田伸一, 岡島清貴, 生沼幸子, ほか：小児心移植の遠 隔期合併症についての検討. 日小児循環器会誌 2006; 22: 6-11

6) Kirk R, Edwards LB, Aurora P, et al: Registry of the International Society for Heart and Lung Transplantation: Registry of the International Society for Heart and Lung Transplantation: Twelfth Official Pediatric Heart Transplantation Report-2009. J Heart Lung Transplant 2009; 28: 993-1006

7)布田伸一, 藤井千恵子, 堀田典寛, ほか : 心移植遠隔期 
における移植心冠動脈病変の検討. 脈管学 2001; 41: 887893

8) 布田伸一：小児心移植の現状. 日本移植学会雑誌 2006; 41: 439-449

9) Kobashigawa JA: Cardiac allograft vasculopathy in heart transplant patients: pathologic and clinical aspects for angioplasty/stenting. J Am Coll Cardiol 2006; 48: 462-463

10) Eisen HJ, Tuzcu EM, Dorent R, et al: Everolimus for the prevention of allograft rejection and vasculopathy in cardiactransplant recipients. N Engl J Med 2003; 349: 847-858

11) Zuckermann A, Manito N, Epailly E, et al: Multidisciplinary insights on clinical guidance for the use of proliferation signal inhibitors in heart transplantation. J Heart Lung Transplant
2008; 27: 141-149

12) Smets F, Sokal EM: Epstein-Bar virus -related lymphoproliferation in children after liver transplant: role of immunity, diagnosis, and management. Pediatr Transplant 2002; 6: 280-287

13) Green M: Management of Epstein-Barr virus-induced posttransplant lymphoproliferative disease in recipients of solid organ transplantation. Am J Transplant 2001; 1: 103-108

14) Majewski M, Korecka M, Joergensen J, et al: Immunosuppressive TOR kinase inhibitor everolimus (RAD) suppresses growth of cells derived from posttransplant lymphoproliferative disorder at allograft-protecting doses. Transplantation 2003; 75: 1710-1717 